\title{
Investigation on amitraz, coumaphos and thymol concentrations in honey produced by Slovenian beekeepers in 2020
}

\author{
Helena BAŠA ČESNIK ${ }^{1^{*}}$, Veronika KMECL ${ }^{1}$
}

Received August 14, 2020; accepted April 09, 2021. Delo je prispelo 14. avgusta 2020, sprejeto 9. aprila 2021.

\begin{abstract}
Investigation on amitraz, coumaphos and thymol concentrations in honey produced by Slovenian beekeepers in 2020

Abstract: A survey on concentrations of veterinary drug residues amitraz, coumaphos and thymol in honey, produced in year 2020 by Slovenian beekeepers, was conducted. 100 samples were analysed: 22 from organic and 78 from conventional production, with two analytical methods. In method for determination of coumaphos and thymol samples were extracted with acetone, petroleumether and dichlorometane. In method for determination of amitraz and its degradation products, samples were hydrolisated with $\mathrm{HCl}$ and $\mathrm{NaOH}$, extractied with n-hexane and derivatisated with heptafluorobutyric anhydride. Determination in both methods was performed with gas chromatograph coupled with mass spectrometer. Measured concentrations of amitraz, coumaphos and thymol were in the range of 0.01-0.12 $\mathrm{mg} \mathrm{kg}^{-1}, 0.02-0.06 \mathrm{mg} \mathrm{kg}^{-1}$ and $0.08-0.17 \mathrm{mg} \mathrm{kg}^{-1}$, respectively. In $61 \%$ of samples analysed no residues of amitraz, thymol and coumaphos were found. Data obtained were compared with the data from literature. Chronic and acute exposure were calculated for consumers. Maximum chronic exposure for amitraz and thymol was $0.1 \%$ and $0.05 \%$ of acceptable daily intake, respectively. Maximum acute exposure for amitraz and thymol was $4 \%$ and $0.8 \%$ of acute reference dose, respectively.

Key words: acaricide residues; GC-MS; amitraz; coumaphos; thymol; honey; consumer exposure
\end{abstract}

Raziskava o koncentracijah amitraza, kumafosa in timola $\mathrm{v}$ medu slovenskih čebelarjev v letu 2020

Izvleček: Izvedli smo raziskavo v kateri smo spremljali ostanke veterinarskih zdravil: amitraza, kumafosa in timola $\mathrm{v}$ medu, ki so ga slovenski čebelarji pridelali v letu 2020. Analizirali smo 100 vzorcev: 22 iz ekološke in 78 iz konvencionalne pridelave, $\mathrm{z}$ dvema analiznima metodama. Pri metodi za določanje kumafosa in timola smo vzorce ekstrahirali $\mathrm{z}$ acetonom, petroletrom in diklorometanom. Pri metodi za določanje amitraza in njegovih razpadnih produktov, smo vzorce hidrolizirali $\mathrm{s} \mathrm{HCl}$ in $\mathrm{NaOH}$, ekstrahirali $\mathrm{z}$ n-heksanom in jih derivatizirali $\mathrm{z}$ heptafluorobutiričnim anhidridom. Določevanje je pri obeh metodah potekalo s plinskim kromatografom sklopljenim $\mathrm{z}$ masnim spektrometrom. Izmerjene koncentracije amitraza, kumafosa in timola so bile v območju $0,01-0,12 \mathrm{mg} \mathrm{kg}^{-1}, 0,02$ $0,06 \mathrm{mg} \mathrm{kg}^{-1}$ oziroma $0,08-0,17 \mathrm{mg} \mathrm{kg}^{-1}$. V $61 \%$ analiziranih vzorcev, nismo določili amitraza, kumafosa in timola. Pridobljene podatke smo primerjali s podatki iz literature. Izračunali smo kronično in akutno izpostavljenost za potrošnike. Maksimalna kronična izpostavljenost za amitraz in timol je bila $0,1 \%$ oziroma $0,05 \%$ sprejemljivega dnevnega vnosa. Maksimalna akutna izpostavljenost za amitraz in timol pa je bila $4 \%$ oziroma $0,8 \%$ akutne referenčne doze.

Ključne besede: ostanki akaricidov: GC-MS; amitraz; kumafos; timol; med; izpostavljenost potrošnikov 


\section{INTRODUCTION}

Honey is produced by honey bees from nectar of plants, as well as from honey dew. It contains carbohydrates, water, traces of organic acids, enzymes, amino acids, pigments, pollen and wax (Anklam, 1998). Besides its nutritional value, honey is nowadays used as natural sweetener, which is very important for diabetics.

Unfortunatelly, honey bees have an enemy called Varroa mite, more precisely Varroa destructor Anderson \& Trueman (2000) described, which represent a great threat to honey bee populations worldwide. Beekeepers can control the mite by using veterinary drugs, which contain amitraz, coumaphos, tau-fluvalinate or flumetrine. In case of organic production only thymol, menthol, eucalyptol, camphor, formic acid, lactic acid, acetic acid and oxalic acid can be used as laid down in Regulation (EC) 889/2008. Consequence is that veterinary drugs utilized for beehive treatments are incorporated into the honey and accumulate in other hive products (Fernandez-Muiño et al., 1995).

In organic production in Slovenia mainly thymol, formic acid, lactic acid and oxalic acid are used. No maximum residue levels (MRLs) are set for these substances in European Union. Thymol residues in honey are safe up to concentration $50 \mathrm{mg} \mathrm{kg}^{-1}$ (Bogdanov et al., 1998). But the taste threshold of thymol in honey is between 1.1 and $1.6 \mathrm{mg} \mathrm{kg}^{-1}$ (Bogdanov et al., 1998). Not to change natural taste of honey, Swiss set MRL for thymol at $0.8 \mathrm{mg} \mathrm{kg}^{-1}$.

The most commonly used veterinary drugs in conventional production in Slovenia are the ones which contain amitraz and coumaphos. European Union MRLs for these two compounds are set in Regulation (EC) 37/2010. MRL for amitraz is $0.2 \mathrm{mg} \mathrm{kg}^{-1}$ and for coumaphos is 0.1 $\mathrm{mg} \mathrm{kg}{ }^{-1}$. Since consumers demand safe products, with veterinary drug residues below MRLs, surveys of such residues are required.

Amitraz and coumaphos were found in honey by different authors: in Polish samples by Gawet et al. (2019), in Spanish samples by Lozano et al. (2019) and in French samples by Wiest et al. (2011). Amitraz was also measured in Spanish honey samples by Juan-Borrás et al. (2016). Coumaphos was also found in Portugese market honey samples by Rial-Otero et al. (2007), in French honey samples by Martel et al. (2002), in Italy organic samples by Chiesa et al. (2016), in Italy honey samples by Del Carlo et al. (2010) and in Polish honey samples by Bargańska et al. (2013). Thymol residues in honey were measured more rarely than the ones for amitraz and coumaphos. Viñas et al. (2006) and Nozal et al. (2002) found thymol in Spanish honey samples and Bogdanov et al. (1998) found thymol in Swiss honey samples.

In present paper, measurements of all three most frequently used acaricides in honey of Slovenian beekeepers, collected in 2020 are presented. Only allowed compounds were tested, meaning that no potential usage of non registered compounds has been investigated. Also, comparison between honey from conventional production and organic production was conducted. Finally, risk assessment was calculated for analysed samples. Our hypothesis was that most frequently amitraz will be used among beekeepers since its degradation time in honey is 10 days (Korta et al., 2001), while for coumaphos it is 9 months (Korta et al., 2001). Thymol is not expected to be used frequently as well, since it can change natural taste of honey.

\section{MATERIAL AND METHODS}

\subsection{SAMPLING}

100 honey samples were collected in June, July and August 2020, from Slovenian beekeepers from all 12 statistical regions in Slovenia. Sampling distribution is presented in Table 1. 78 samples originated from conventional production, meaning that beekeepers reported use of amitraz, coumaphos, thymol, flumethrin, formic acid, lactic acid and/or oxalic acid to supress varroa and 22 samples from organic production, meaning that beekeepers reported only use of thymol, formic acid, lactic acid and/or oxalic acid to supress varroa.

\section{2.ANALYTICAL PROCEDURE}

Amitraz and its degradation products (all metabolites containing the 2,4-dimethylaniline moiety)

After sample hydrolisation with $2 \mathrm{~N} \mathrm{HCl}$ and $2 \mathrm{M}$ $\mathrm{NaOH}$, extraction was performed with $\mathrm{n}$-hexane, followed by derivatisation with heptafluorobutyric anhydride (HFBA). Determination was conducted with gas chromatograph coupled with mass spectrometer (GCMS). Method is in detail described elsewhere (Kmecl \& Baša Česnik, 2011; Baša Česnik et al., 2019).

Coumaphos and thymol

Samples were dissolved in water and then extracted with mixture of acetone, petroleumether and dichlorometane at ratio 1:2:2 $(\mathrm{v} / \mathrm{v} / \mathrm{v})$. Determination was conducted with GC-MS. Method is in detail described elsewhere (Baša Česnik et al., 2019).

Quality assurance

Each series of analyses included one or two spiked samples of commodity analysed. Recoveries were 70-120 
Table 1: Sampling distribution

\begin{tabular}{lccc}
\hline Statistical region & $\begin{array}{c}\text { No. of samples from conventional } \\
\text { production }\end{array}$ & $\begin{array}{c}\text { No. of samples from organic } \\
\text { production }\end{array}$ & Sum \\
\hline Gorenjska & 4 & 2 & 6 \\
Goriška & 9 & 2 & 11 \\
Jugovzhodna Slovenija & 4 & 3 & 7 \\
Koroška & 4 & 0 & 4 \\
Notranje kraška & 5 & 0 & 5 \\
Obalno kraška & 7 & 2 & 9 \\
Osrednja Slovenija & 8 & 3 & 11 \\
Podravska & 6 & 1 & 7 \\
Pomurska & 10 & 1 & 11 \\
Savinjska & 15 & 5 & 20 \\
Spodnje posavska & 4 & 2 & 6 \\
Zasavska & 2 & 1 & 3 \\
Sum & 78 & 22 & 100 \\
\hline
\end{tabular}

$\%$. In SANTE/11813/2017 requirement for recoveries is $60-140 \%$.

\section{3. RISK ASSESSMENT}

Chronic exposure

The calculation of long-term exposure was performed with the EFSA PRIMo model revision 3.1, accessible on the internet at https://www.efsa.europa.eu/ en/applications/pesticides/tools. The Supervised Trial Median Residue (STMR) was calculated from all samples analysed. It was compared to the Acceptable Daily Intake (ADI) of a single active substance. Chronic consumer exposure was expressed in \% of the ADI. The acceptable limit for long-term exposure is $100 \%$ of the ADI.

\section{Acute exposure}

The calculation of short-term exposure was performed with the EFSA PRIMo model revision 3.1, accessible on the internet at https://www.efsa.europa.eu/en/ applications/pesticides/tools.

The Highest Residue (HR) was compared to the Acute Reference Dose (ARfD) of a single active substance. Acute consumer exposure was expressed in \% of ARfD. The acceptable limit for short-term exposure is $100 \%$ of the ARfD.

\section{RESULTS AND DISCUSSION}

In 43 samples from conventional production (55.1
$\%)$, no residues of amitraz, coumaphos and thymol were found. Amitraz, coumaphos and thymol residues were found in $29(37.2 \%), 7$ (9.0\%) and $3(3.8 \%)$ samples from conventional production respectively. Multiple residues in conventional production were found only in 4 samples (5.1\%): 3 samples contained residues of amitraz and coumaphos (3.8\%) and 1 sample contained residues of amitraz and thymol (1.3\%). No MRL exceedances were observed for any of the substances analysed. Results are presented in Table 2.

In 18 samples from organic production ( $81.8 \%)$, no residues of amitraz, coumaphos and thymol were found. Amitraz, coumaphos and thymol residues were found in $2(9.1 \%), 1(4.5 \%)$ and $1(4.5 \%)$ samples from organic production respectively. It was expected that thymol would be present in larger amount of samples in organic production, but beekeepers obviously prefer the use of formic acid, and oxalic acid to supress varroa, probably because of fear to change sensory characteristics of honey. Multiple residues in organic production were not found. No MRL exceedances were observed for any of the substances analysed. Results are presented in Table 2.

The highest concentration of amitraz in conventional production was found in Pomurska region (0.12 $\mathrm{mg} \mathrm{kg}^{-1}$ ) and in organic production in Jugovzhodna Slovenija region $\left(0.03 \mathrm{mg} \mathrm{kg}^{-1}\right)$. The highest concentration of coumaphos in conventional production was found in Osrednja Slovenija region and in organic production in Gorenjska region $\left(0.02 \mathrm{mg} \mathrm{kg}^{-1}\right)$. The highest concentration of thymol in conventional production was found in Savinjska region $\left(0.17 \mathrm{mg} \mathrm{kg}^{-1}\right)$ and in organic production in Spodnje posavska region $\left(0.16 \mathrm{mg} \mathrm{kg}^{-1}\right)$. Results are presented in Table 3. 
Table 2: Amitraz, coumaphos and thymol residues in honey samples in 2020

\begin{tabular}{lccc}
\hline & amitraz & coumaphos & thymol \\
\hline LOQ $\left(\mathrm{mg} \mathrm{kg}^{-1}\right)$ & 0.01 & 0.009 & 0.07 \\
MRL $\left(\mathrm{mg} \mathrm{kg}^{-1}\right)$ & $0.2(\mathrm{a})$ & $0.1(\mathrm{a})$ & $/$ \\
& conventional production & & \\
\hline Min concentration $\left(\mathrm{mg} \mathrm{kg}^{-1}\right)$ & 0.01 & 0.02 & 0.08 \\
Max concentration $\left(\mathrm{mg} \mathrm{kg}^{-1}\right)$ & 0.12 & 0.06 & 0.17 \\
Average $\left(\mathrm{mg} \mathrm{kg}^{-1}\right)$ & 0.03 & 0.04 & 0.12 \\
SD (mg kg-1) & 0.03 & 0.02 & 0.04 \\
No. of samples where residues were found & 29 & 7 & 3 \\
& organic production & & 0.16 \\
\hline Min concentration $\left(\mathrm{mg} \mathrm{kg}^{-1}\right)$ & 0.01 & 0.02 & 0.16 \\
Max concentration $\left(\mathrm{mg} \mathrm{kg}^{-1}\right)$ & 0.03 & 0.02 & 0.16 \\
Average $\left(\mathrm{mg} \mathrm{kg}^{-1}\right)$ & 0.02 & 0.02 & $/$ \\
SD (mg kg-1) & 0.02 & $/$ & 1 \\
No. of samples where residues were found & 2 & 1 & \\
\hline
\end{tabular}

(a) Regulation (EC) $37 / 2010$

LOQ means limit of quantification of the method

MRL means maximum residue limit

SD means standard deviation

Table 3: Range of concentrations in honey samples according to region in 2020

\begin{tabular}{|c|c|c|c|c|c|c|}
\hline & Amitraz & Amitraz & Coumaphos & Coumaphos & Thymol & Thymol \\
\hline & Conventional & Organic & Conventional & Organic & Conventional & Organic \\
\hline & $\operatorname{conc}\left(\mathrm{mg} \mathrm{kg}^{-1}\right)$ & $\operatorname{conc}\left(\mathrm{mg} \mathrm{kg}^{-1}\right)$ & conc $\left(\mathrm{mg} \mathrm{kg}^{-1}\right)$ & $\operatorname{conc}\left(\mathrm{mg} \mathrm{kg}^{-1}\right)$ & $\operatorname{conc}\left(\mathrm{mg} \mathrm{kg}^{-1}\right)$ & conc $\left(\mathrm{mg} \mathrm{kg}^{-1}\right)$ \\
\hline Gorenjska & $0.02-0.07$ & n.d. & n.d. & 0.02 & n.d. & n.d. \\
\hline Goriška & $0.01-0.08$ & n.d. & n.d. & n.d. & 0.08 & n.d. \\
\hline $\begin{array}{l}\text { Jugovzhodna } \\
\text { Slovenija }\end{array}$ & n.d. & 0.03 & n.d. & n.d. & n.d. & n.d. \\
\hline Koroška & 0.01 & n.a. & $0.02-0.04$ & n.a. & n.d. & n.a. \\
\hline Notranje kraška & 0.06 & n.a. & n.d. & n.a. & n.d. & n.a. \\
\hline Obalno kraška & $0.01-0.02$ & n.d. & n.d. & n.d. & n.d. & n.d. \\
\hline Osrednja Slovenija & 0.02 & n.d. & 0.06 & n.d. & n.d. & n.d. \\
\hline Podravska & n.d. & n.d. & 0.03-0.05 & n.d. & n.d. & n.d. \\
\hline Pomurska & $0.01-0.12$ & 0.01 & 0.02 & n.d. & n.d. & n.d. \\
\hline Savinjska & $0.01-0.03$ & n.d. & 0.04 & n.d. & $0.12-0.17$ & n.d. \\
\hline Spodnje posavska & $0.05-0.07$ & n.d. & n.d. & n.d. & n.d. & 0.16 \\
\hline Zasavska & n.d. & n.d. & n.d. & n.d. & n.d. & n.d. \\
\hline
\end{tabular}

n.a means not analysed

n.d. means not determined 
Table 4: Ratio of positive honey samples according to region in 2020

\begin{tabular}{|c|c|c|c|c|c|c|}
\hline & Amitraz & Amitraz & Coumaphos & Coumaphos & Thymol & Thymol \\
\hline & Conventional & Organic & Conventional & Organic & Conventional & Organic \\
\hline & Ratio (\%) & Ratio (\%) & Ratio (\%) & Ratio (\%) & Ratio (\%) & Ratio (\%) \\
\hline Gorenjska & 50.0 & 0.0 & 0.0 & 50.0 & 0.0 & 0.0 \\
\hline Goriška & 33.3 & 0.0 & 0.0 & 0.0 & 11.1 & 0.0 \\
\hline Jugovzhodna Slovenija & 0.0 & 33.3 & 0.0 & 0.0 & 0.0 & 0.0 \\
\hline Koroška & 25.0 & n.a. & 50.0 & n.a. & 0.0 & n.a. \\
\hline Notranje kraška & 20.0 & n.a. & 0.0 & n.a. & 0.0 & n.a. \\
\hline Obalno kraška & 57.1 & 0.0 & 0.0 & 0.0 & 0.0 & 0.0 \\
\hline Osrednja Slovenija & 12.5 & 0.0 & 12.5 & 0.0 & 0.0 & 0.0 \\
\hline Podravska & 0.0 & 0.0 & 33.3 & 0.0 & 0.0 & 0.0 \\
\hline Pomurska & 80.0 & 100.0 & 10.0 & 0.0 & 0.0 & 0.0 \\
\hline Savinjska & 46.7 & 0.0 & 6.7 & 0.0 & 13.3 & 0.0 \\
\hline Spodnje posavska & 50.0 & 0.0 & 0.0 & 0.0 & 0.0 & 50.0 \\
\hline Zasavska & 0.0 & 0.0 & 0.0 & 0.0 & 0.0 & 0.0 \\
\hline
\end{tabular}

n.a. means not analysed

The highest ratio of positive samples (where active substance was found) for amitraz was observed in Pomurska region in conventional and organic production. Amitraz was not found in Podravska and Zasavska regions in conventional and organic production. Coumaphos was in conventional production most frequently found in Koroška region and in organic production in Gorenjska region. Coumaphos was not found in conventional and organic production in Goriška, Jugovzhodna Slovenija, Obalno kraška, Spodnje posavska and Zasavska regions. Thymol was in conventional production most frequently found in Savinjska region and in organic production in Spodnje posavska region. Thymol was not found in conventional and organic production in Gorenjska, Jugovzhodna Slovenija, Obalno kraška, Osrednja Slovenija, Podravska, Pomurska, and Zasavska regions. Results are presented in Table 4.

Amitraz was found in $31 \%$ of samples analysed in year 2020. It was also the most frequently found in years 2016 (unpublished results), 2017 (Baša Česnik and Kmecl, 2017), 2018 (Baša Česnik and Kmecl, 2018) and 2019 (Baša Česnik and Kmecl 2019) in 24 \%, 30 \%, 28 \% and $46 \%$ of samples analysed respectively. Coumaphos was found in $8 \%$ of samples analysed in year 2020. It was also the second most frequently found substance in years 2016 (unpublished results), 2017 (Baša Česnik and Kmecl, 2017), 2018 (Baša Česnik and Kmecl, 2018) and 2019 (Baša Česnik and Kmecl 2019) in 5 \%, $10 \%$,
$6 \%$ and $7 \%$ of samples analysed respectively. The least frequently found was thymol in $4 \%$ of samples in 2020. It was also the least frequently found substance in years 2016 (unpublished results), 2017 (Baša Česnik and Kmecl, 2017), 2018 (Baša Česnik and Kmecl, 2018) and 2019 (Baša Česnik and Kmecl 2019) in $3 \%, 1 \%, 3 \%$ and $4 \%$ of samples analysed respectively.

Risk assessment for samples from year 2020 was conducted for amitraz and thymol only, since no ADI and ARfD are available for coumaphos. Chronic risk assessment for amitraz was conducted with ADI $0.003 \mathrm{mg}$ $(\mathrm{kg} \mathrm{bw})^{-1} \mathrm{~d}^{-1}$ and STMR $0.02 \mathrm{mg} \mathrm{kg}^{-1}$. It resulted in $0.1 \%$ of ADI maximum, for consumer group DE child. This represented maximum amitraz exposure through honey of $0.002 \mu \mathrm{g}(\mathrm{kg} \mathrm{bw})^{-1} \mathrm{~d}^{-1}$. Acute risk assessment for amitraz was conducted with ARfD $0.01 \mathrm{mg} \mathrm{kg} \mathrm{bw}^{-1}$ and HR $0.12 \mathrm{mg} \mathrm{kg}^{-1}$. It resulted in $4 \%$ of ARfD maximum, for consumer group children. This represented maximum amitraz exposure through honey of $0.43 \mu \mathrm{g}(\mathrm{kg} \mathrm{bw})^{-1}$ with one meal. Chronic risk assessment for thymol was conducted with ADI $0.03 \mathrm{mg}(\mathrm{kg} \mathrm{bw})^{-1} \mathrm{~d}^{-1}$ and STMR 0.14 $\mathrm{mg} \mathrm{kg}^{-1}$. It resulted in $0.05 \%$ of ADI maximum, for consumer group DE child. This represented thymol exposure through honey of $0.01 \mu \mathrm{g}(\mathrm{kg} \mathrm{bw})^{-1} \mathrm{~d}^{-1}$. Acute risk assessment for thymol was conducted with ARfD $0.08 \mathrm{mg}(\mathrm{kg}$ bw) $)^{-1}$ and HR $0.17 \mathrm{mg} \mathrm{kg}^{-1}$. It resulted in $0.8 \%$ of ARfD maximum, for consumer group children. This represented maximum thymol exposure through honey of $0.61 \mu \mathrm{g}$ 
(kg bw $)^{-1}$ with one meal. Low chronic exposure for consumers means that analysed honey can be consumed by all consumer groups: children, adults and elderly people every day of their life without risk that it would affect their health. Low acute exposure for consumers means that analysed honey can be consumed with one meal without risk that it would affect consumers health. Based on calculations it can be concluded that analysed honey represents no unacceptable risk for consumers.

In literature we found data for amitraz concentrations in honey from different authors. Lozano et al. (2019) found amitraz in Spanish honey samples up to concentration $0.648 \mathrm{mg} \mathrm{kg}^{-1}$. Gawet et al. (2019) found amitraz in Polish honey samples in concentrations up to $0.6 \mathrm{mgkg}^{-1}$ Wiest et al. (2011) found amitraz in French honey samples up to concentration $0.116 \mathrm{mg} \mathrm{kg}^{-1}$. JuanBorrás et al. (2016) found amitraz in Spanish market honey samples up to concentration $0.05 \mathrm{mg} \mathrm{kg}^{-1}$. Highest concentration found in 2020 in Slovenia $\left(0.12 \mathrm{mg} \mathrm{kg}^{-1}\right)$ is comparable to French one, but lower than in Polish samples and Spanish samples measured by Lozano et al. (2019) and at the same time higher than in Spanish samples measured by Juan-Borrás et al. (2016).

Coumaphos concentrations in honey were even more frequently reported in literature than the ones for amitraz. Martel \& Zeggane (2002) found coumaphos in French honey samples in concentrations up to level 0.26 mg kg-1. Del Carlo et al. (2010) and Chiesa et al. (2016) found coumaphos in honey samples from Italy: the first one up to concentration $0.084 \mathrm{mg} \mathrm{kg}^{-1}$ and the second one up to concentration $0.00206 \mathrm{mg} \mathrm{kg}^{-1}$ (the last ones were organic samples). Gawet et al. (2019) and Bargańska et al. (2013) found coumaphos in Polish honey: the first one in concentrations up to $0.039 \mathrm{mg} \mathrm{kg}^{-1}$ and the second one in concentrations up to $0.0167 \mathrm{mg} \mathrm{kg}^{-1}$. Lozano et al. (2019) found coumaphos in Spanish honey samples up to concentration $0.036 \mathrm{mg} \mathrm{kg}^{-1}$. Wiest et al. (2011) found coumaphos in French honey samples up to concentration $0.029 \mathrm{mg} \mathrm{kg}^{-1}$. Juan-Borrás (2016) found coumaphos in Spanish market honey samples up to concentration $0.013 \mathrm{mg} \mathrm{kg}^{-1}$. Rial-Otero et al. (2007) found coumaphos in Portugese market honey samples in concentrations up to $0.000015 \mathrm{mg} \mathrm{kg}^{-1}$. The highest concentration found in 2020 in Slovenia $\left(0.06 \mathrm{mg} \mathrm{kg}^{-1}\right)$ is lower than in French samples measured by Martel \& Zeggane (2002) and Italian samples measured by Del Carlo et al. (2010) and at the same time higher than in Polish, Spain, Portugese samples, Italian samples measured by Chiesa et al. (2016) and French samples measured by Wiest et al. (2011).

In literature, thymol residues in honey were reported more rarely than for amitraz and coumaphos. Viñas et al. (2006) and Nozal et al. (2002) measured thymol in Spanish honey samples: the first one in concentrations up to $0.000346 \mathrm{mg} \mathrm{kg}^{-1}$ and the second one in concentrations up to $0.00036 \mathrm{mg} \mathrm{kg}^{-1}$. Bogdanov et al. (1998) measured thymol in Swiss honey samples in concentrations up to $0.48 \mathrm{mg} \mathrm{kg}^{-1}$. Highest concentration found in 2020 in Slovenia $\left(0.17 \mathrm{mg} \mathrm{kg}^{-1}\right)$ is higher than in Spanish samples, but lower than in Swiss samples.

\section{CONCLUSIONS}

In $61 \%$ of samples analysed no residues of amitraz, thymol and coumaphos were found. No MRL exceedances were observed in any of the samples. Amitraz was the most frequently found substance in honey produced in year 2020. We quantified it in $31 \%$ of samples analysed. The second most frequently found substance was coumaphos, which was quantified in $8 \%$ of samples. The least frequently found was thymol, which was quantified in $4 \%$ of samples analysed. Risk assessment revealed that the analysed honey is safe for consumers. Concentrations of amitraz, coumaphos and thymol in Slovenian honey from 2020 are in range of data found in literature.

\section{ACKNOWLEDGEMENTS}

The authors would like to thank Mojca Trček, Sonja Dolinšek, Bojana Grofelnik and Sonja Arhar for help with extracts preparation and sample collection. The results achieved were generated within the framework of the Beekeeping Program in the Republic of Slovenia for the years 2020-2022, which was financed from the state budget and the budget of the European Union. The authors also acknowledge the financial support from the Horizon 2020-METROFOOD project (Grant Agreement no. 871083) for data processing.

\section{REFERENCES}

Anderson, D.L., Trueman, J.W.H. (2000). Varroa jacobsoni (Acari: Varroidae) is more than one species. Experimental and Applied Acarology, 24, 165-189. https://doi. org/10.1023/A:1006456720416

Anklam, E. (1998). A review of the analytical methods to determine the geographical and botanical origin of honey. Food Chemistry, 63, 549-562. https://doi.org/10.1016/S03088146(98)00057-0

Bargańska, Ż., Ślebioda, M., Namieśnik, J. (2013). Pesticide residues levels in honey from apiaries located of Northern Poland. Food Control, 31, 196-201. https://doi.org/10.1016/j. foodcont.2012.09.049

Baša Česnik, H., Kmecl, V. (2017). Vsebnost nekaterih akari- 
cidov v medu slovenskih čebelarjev v letu 2017. Kemija $v$ šoli in družbi, year 29, no. 1, pp 1-5, http://www.kemija.net/

Baša Česnik, H., Kmecl, V. (2018). Vsebnost nekaterih akaricidov v medu slovenskih čebelarjev v letu 2018. Kemija $v$ šoli in družbi, year 2018, no. 1, pp. 1-4. https://www.kemija.net/ stevilke/224

Baša Česnik, H., Kmecl, V. (2019). Vsebnost nekaterih akaricidov v medu slovenskih čebelarjev v letu 2019. Kemija $v$ šoli in družbi, year 2019, no. 1, pp. 1-5. https://www.kemija.net/ stevilke/225

Baša Česnik, H., Kmecl, V., Velikonja Bolta, Š. (2019). Pesticide and veterinary drug residues in honey - validation of methods and a survey of organic and conventional honeys from Slovenia. Food Additives and Contaminants Part A, 36, 1358-1375. https://doi.org/10.1080/19440049.2019.163 1492

Bogdanov, S., Imdorf, A., Kilchenmann, V. (1998). Residues in wax and honey after Apilife VAR treatment. Apidologie, 29, 513-524. https://doi.org/10.1051/apido:19980604

Chiesa, L.M., Labella, G.F., Giorgi, A., Panseri, S., Pavlovic, R., Bonacci, S., Arioli, F. (2016). The occurrence of pesticides and persistent organic pollutants in Italian organic honeys from different productive areas in relation to potential environmental pollution. Chemosphere, 154, 482-490. https:// doi.org/10.1016/j.chemosphere.2016.04.004

Del Carlo, M., Pepe, A., Sergi, M., Mascini, M., Tarentini, A., Compagnone, D. (2010). Detection of coumaphos in honey using a screening method based on an electrochemical acetylcholinestearase bioassay. Talanta, 81: 76-81. https://doi. org/10.1016/j.talanta.2009.11.038

Fernandez-Muiño, M.A., Sancho, M.T., Muniategui, S., Huidobro, J.F., Simal-Lozano, J. (1995). Acaricide residues in honey: analytical methods and levels found, Journal of Food Protection, 58, 449-454. https://doi.org/10.4315/0362028X-58.4.449

Gawet, M., Kiljanek, T., Niewiadowska, A., Semeniuk, S., Goliszek, M., Burek, O., Posyniak, A. (2019). Determination of neonicotinoids and 199 other pesticide residues in honey by liquid and gas chromatography coupled with tandem mass spectrometry. Food Chemistry, 282, 36-47. https://doi. org/10.1016/j.foodchem.2019.01.003

Juan-Borrás, M., Domench, E., Escriche, I. (2016). Mixturerisk-assessment of pesticide residues in retail polyfloral honey. Food Control, 67, 127-134. https://doi.org/10.1016/j. foodcont.2016.02.051

Kmecl, V., Baša Česnik, H. (2011). A survey of total amitraz residues in honey produced in Slovenia. In: J. Pulkrabová (Ed.), M. Tomaniová (Ed.). Book of abstracts, $5^{\text {th }}$ International Symposium on Recent Advances in Food Analysis (pp. 407). Prague: Institute of Chemical Technology.

Korta, E., Bakkali, A., Berrueta, L.A., Gallo, B., Vicente, F., Kilchenmann, V., Bogdanov, S. (2001). Study on acaricide stability in honey. Characterization of amitraz degradation products in honey and beeswax. Journal of Agricultural and food Chemistry, 49, 5835-5842. https://doi.org/10.1021/ jf010787s

Lozano, A., Hernando, M.D., Uclés, S., Hakme, E., FernádezAlba, A.R. (2019). Identification and measurement of veterinary drug residues in beehive products. Food Chemistry, 274,61-70. https://doi.org/10.1016/j.foodchem.2018.08.055

Martel, A.C. \& Zeggane S. (2002). Determination of acaricides in honey by high-performance liquid chromatography with photodiode array detection. Journal of Chromatography $A, 954$, 173-180. https://doi.org/10.1016/ S0021-9673(02)00126-7

Nozal, M.J., Bernal, J.L., Jiménez, J.J., González, M.J., Higes, M. (2002). Extraction of thymol, eucalyptol, menthol, and camphor residues from honey and beeswax. Determination by gas chromatography with flame ionization detection. Journal of Chromatography A, 954, 207-215. https://doi. org/10.1016/S0021-9673(02)00153-X

Rial-Otero, R., Gaspar, E.M., Moura, I., Capelo, J.L. (2007). Gas chromatography mass spectrometry determination of acaricides from honey after a new fast ultrasonic-based soild phase micro-extraction sample treatment. Talanta, 71, 1906-1914. https://doi.org/10.1016/j.talanta.2006.08.035

SANTE/11813/2017. Guidance document on analytical quality control and method validation procedures for pesticide residues analysis in food and feed. DG SANTE, European Comission, 2017.

Viñas, P., Soler-Romera, M.J., Hernández-Córdoba, M. (2006). Liquid chromatographic determination of phenol, thymol and carvacrol in honey using fluorimetric detection. Talanta, 69, 1063-1067. https://doi.org/10.1016/j.talanta.2005.12.030

Wiest, L., Buleté, A., Giroud, B., Fratta, C., Amic, S., Lambert, O., Pouliquen, H., Arnaudguilhem, C. (2011). Multi-residue analysis of 80 environmental contaminants in honeys, honeybees and pollens by one extraction procedure followed by liquid and gas chromatography coupled with mass spectrometric detection. Journal of Chromatography A, 1218, 57435756. https://doi.org/10.1016/j.chroma.2011.06.079 